\section{Acknowledgment of Referees}

As a refereed journal, the success of Politics and the Life Sciences depends on the generosity of a great many scholars who donate their time and expertise to review manuscripts. The scholars listed below reviewed one or more manuscripts for $P L S$ in 1996. We extend our sincere thanks for their vital contribution to the journal's mission.

$\begin{array}{ll}\text { George Annas } & \text { Kenneth C. Land } \\ \text { Patricia A. Baird } & \text { George E. Markus } \\ \text { David Barash } & \text { Brian Martin } \\ \text { Carol Barner-Barry } & \text { Roger Masters } \\ \text { Robert Blank } & \text { Deborah Mathieu } \\ \text { William Brandon } & \text { Mary Maxwell } \\ \text { Arthur Caplan } & \text { Kevin McGuire } \\ \text { Ira Carmen } & \text { Linda Mealey } \\ \text { Marie Chevrier } & \text { Janna Merrick } \\ \text { Leonard Cole } & \text { Dorothy Nelkin } \\ \text { John Douard } & \text { Francois Nielsen } \\ \text { Elaine Draper } & \text { Karen O'Connor } \\ \text { Lee Ellis } & \text { Diane Paul } \\ \text { Vincent Falger } & \text { Robert P. Rhodes } \\ \text { Diana Fishbein } & \text { Marc Howard Ross } \\ \text { Mark S. Frankel } & \text { J. David Singer } \\ \text { Brian A. Gladue } & \text { Jonathan Tucker } \\ \text { Henry Glick } & \text { Gordon Vachon } \\ \text { David Goetze } & \text { Tatu Vanhanen } \\ \text { Doris A. Graber } & \text { David Weimer } \\ \text { Roger Handberg } & \text { Dorothy Wertz } \\ \text { Kathi Hanna } & \text { Mark Wheelis } \\ \text { Yuwa Hedrick-Wong } & \text { Elliott White } \\ \text { Helen Bequaert Holmes } & \text { David Wilsford } \\ \text { Nancy Kassop } & \text { Stephen C. Zehr } \\ \text { Sheldon Krimsky } & \text { Raymond Zilinskas } \\ \text { Sanford Lakoff } & \\ & \end{array}$

\section{APLS Annual Meeting}

The 1997 annual meeting of the Association for Politics and the Life Sciences will be held in conjunction with the meeting of the American Political Science Association, August 28-31, 1997 in Washington, DC. The program chair-for a program that is now complete-is Robert Blank, Department of Political Science, University of Canterbury, Christchurch, New Zealand (fax: +64-33-642-007; E-mail: POLS049@CSC.CANTERBURY.AC.NZ.Panel and paper proposals were due by December 15, 1996. For additional information about the APLS meeting, contact Executive Director Gary R. Johnson, Association for Politics and the Life Sciences, Lake Superior State University, Sault Ste. Marie, MI 49783-1699, USA; tel: +1-906-635-2757; fax: +1-906-635-2111; E-mail: APLS@LAKERS.LSSU.EDU. For information about registration and lodging, contact the American Political Science Association, 1527 New Hampshire Ave., N.W., Washington, DC 20036, USA; tel: +1202-483-2512; fax: +1-202-483-2657; e-mail: MEETING @APSA.COM.

\section{Council and Officer Election}

Elected or reelected to four-year terms (1996-2000) on the APLS Executive Council in the election of 1996 were Robert Blank (University of Canterbury), Ira Carmen (University of Illinois), Samuel Hines (College of Charleston), Joseph Losco (Ball State University), Janna Merrick (University of South Florida), and Steven Peterson (Alfred University). They join Larry Arnhart (Northern Illinois University), Carol Barner-Barry (University of Maryland, Baltimore County), Andrea Bonnicksen (Northern Illinois University), Odelia Funke (U.S. Environmental Protection Agency), Roger Masters (Dartmouth College), and Albert Somit (Southern Illinois University), who will be serving the final two years of four-year terms that end in 1998. Elected by the council itself to serve as officers were Samuel Hines, Chair; Andrea Bonnicksen, Vice-Chair; and Ira Carmen, Secretary. Congratulations to all.

\section{Kennedy Institute of Ethics Courses}

The Kennedy Institute of Ethics at Georgetown University will offer an Intensive Bioethics Course, "Contemporary Challenges in Health Care Ethics," June 7-12, 1997. This course provides a broad and intensive exploration of bioethics. Participants are introduced to the basics of ethical theory and methods, and key concepts are explored by examining some of the most challenging ethical topics facing those in health care. The course is directed primarily toward physicians, nurses, and policymakers in the health care field.

Standard tuition is $\$ 1350$. This fee includes course materials, continuing education credits (if desired), breakfasts and lunches, receptions and an evening banquet, but does not include dinners or lodging. Reduced tuition is available 
for graduate students, and some partial scholarships are available to those without institutional funding. For more information, contact the Course Coordinator, Kennedy Institute of Ethics, Box 571212, Georgetown University, Washington, DC 20057-1212, USA; tel: +1-202-6876771; fax: +1-202-687-8089. E-mail: KICOURSE@ GUNET.GEORGETOWN.EDU; WWW: HTTP:// GUWEB.GEORGETOWN.EDU/KENNEDY/.

\section{Evolution of Morality}

The 4th annual Star Island Conference (held off the coast of New Hampshire) will be sponsored by The Institute on Religion in an Age of Science, from July 26 to August 2, 1997. Conference co-chairs are Michael Ruse, editor of Biology and Philosophy, and Karl Peters, editor of Zygon: Journal of Religion and Science. This year's theme is "the evolution of morality." For more information, contact Bonnie Falla, Registrar, 810 North 9th Street, Allentown, PA 18102, USA; telephone: +1-610-432-8711.

\section{IPSA World Congress}

The 17th World Congress of the International Political Science Association will take place in Seoul, Korea, August 17-21, 1997. The congress will feature over 280 sessions, with participation of over 2,000 political scientists from around the world. Research Committee \#12 (Biology and Politics) will sponsor two panels. For information, contact Steven A. Peterson, Division of Social Sciences, 1 Saxon Drive, Alfred University, Alfred, NY 14802, USA; tel: +1-607-871-2215; fax: +1-607-871-2114; E-mail: FPETERSON@BIGVAX.ALFRED.EDU.

\section{Biological Perspectives in the Social Sciences}

The Gruter Institute for Law and Behavioral Research is sponsoring its fourth annual faculty seminar on "Biological Perspectives in the Social Sciences" at Dartmouth College from August 2 (evening) through August 18, 1997 (noon). The seminar will be directed by Roger D. Masters (Department of Government, Dartmouth). Visiting lecturers will represent diverse fields in the biological and social sciences. Past speakers have included Robert Trivers (Evolutionary Theory), Michael T. McGuire (Neurobiology and Behavior), Frans de Waal (Primate Behavior), Miguel MarinPadilla (Neuroscience), Helen Fisher (Anthropology), Roger Masters (Political Science), Lionel Tiger (Sociology), Robert Frank (Economics), E. Donald Elliott (Law), Edward Berger (Genetics), Peter Richerson (Cultural Evolution), and Randy Nesse (Evolutionary Medicine).

Single dormitory rooms, with shared bath, have been reserved at Dartmouth College at US\$35 per night. If desired, other lodging is available in the Hanover area. The registration fee is US\$200. A limited number of grants covering the expenses of room, board, and registration are available to scholars and graduate students whose teaching or research links biological perspectives to the social sciences or humanities. For applications to attend and for inquiries about grants and other matters, contact Ms. Suzanne Saxton, Gruter Institute for Law and Behavioral Research, c/o Department of Government, Silsby 6108, Dartmouth College, Hanover, NH 03755-3514, USA; tel: +1-603-646-1029; fax: +1-603-646-2152; E-mail: GRUTER.INSTITUTE@DARTMOUTH.EDU.

\section{Human Behavior and Evolution Society}

The 1997 annual meeting of the Human Behavior and Evolution Society (HBES) will be held June 4-8, 1997 at the University of Arizona in Tucson, Arizona. The meeting's keynote speaker will be Frans de Waal. Plenary speakers will be John Alcock, Robert Boyd, Steve Gangestad, Daniel Perusse, Lawrence Keeley, Neil Malamuth, Lewis Petrinovich, and Barbara Smuts. Program chairs are Mark Flinn, University of Missouri, and David C. Rowe and James King, University of Arizona. Local hosts are Aurelio Jose Figueredo and Mary Wetzel. The deadline for abstracts for proposed presentations is March 15, 1997. Deadline for registration is April 21, 1997. For more information about the conference and about submitting a proposal, visit the conference's web site at HTTP://HBES97.ARIZONA. EDU.

\section{Bioethics Meetings in Japan}

Four bioethics meetings will convene in Japan between October 30 and November 8, 1997. The Third International Tsukuba Bioethics Roundtable (in English) will meet October 30 to November 2, 1997 in Tsukuba Science City. The theme is "Universality and Diversity in Bioethics: What Japanese Bioethics Can Offer to the International Community." Overlapping with this meeting, on November 1-2, and in the same location, the Ninth Annual Meeting of the Japan Association of Bioethics will take place (in Japanese). The theme will be "Bioethics for the Global Community: Anthropology, Philosophy, and Social Justice."

The UNESCO Asian Bioethics Conference (ABC'97) will be held November 4-7 in Kobe (Japanese/English simultaneous translation). This meeting includes the Second Congress of the East Asian Association of Bioethics and the Third MURS Japan International Symposium. The Sixth International Bioethics Seminar in Fukui will be held November 7-8 in (in English).

For all of these meetings, participants are requested to provide a Japanese (if a Japanese speaker) and an English abstract, which would be published on the internet (Eubios 
Ethics Institute world wide web site: HTTP://WWW. BIOL.TSUKUBA.AC.JP/ MACER/INDEX.HTML). The goal is to make Asian and Japanese bioethics more accessible to the international community. The program will be updated through the site for the ABC (HTTP:// WWW.BIOL.TSUKUBA.AC.JP/ MACER/ABC.HTML). For more information, contact Dr. Darryl Macer, Institute of Biological Sciences, University of Tsukuba, Tsukuba Science City, Ibaraki 305, Japan; tel: +81-298-53-4662; fax: +81-298-53-6614; E-mail: MACER@SAKURA.CC. TSUKUBA.AC.JP.

\section{European Sociobiological Society}

The 1997 annual meeting of the European Sociobiological Society (ESS) will be held July 7-9, 1997 in Ghent, Belgium. The main theme of the conference will be "The Sociobiology of In-Group/Out-Group Behavior, Part 2" (a follow-up to the 1987 Oxford Conference, which resulted in publication of The Sociobiology of Ethnocentrism (Croom Helm/Georgia University Press, 1987). Local organizers are Robert Cliquet and Kristiaan Thienpont. For additional information, contact Kristiaan Thienpont, Department of Political Science, University of Ghent, St.-Pietersnieuwstratt 49, B-9000 Ghent, Belgium; tel: +32-9-264-42-48; fax: +32-9-264-42-94; E-mail: KRISTIAAN.THIENPONT@RUG.AC.BE.

\section{8-99 Fulbright Scholar Awards}

Competition for 1998-99 Fulbright Scholar Awards opens March 1, 1997. Opportunities for lecturing or advanced research in over 135 countries are available to college and university faculty and professionals outside academe. Awards range from two months to a full academic year, and many assignments are flexible to the needs of the grantee. Virtually all disciplines participate. Openings exist in almost every area of the arts and humanities, social sciences, natural and applied sciences, and professional fields such as business, journalism, and law.

Basic eligibility requirements are U.S. citizenship and the $\mathrm{Ph}$.D. or comparable professional qualifications (for certain fields such as the fine arts or TESOL, the terminal degree in the field may be sufficient). University or college teaching experience is expected for lecturing awards, and language skills are needed for some countries, although most lecturing assignments are in English. Funding for the Fulbright program is provided by the United States Information Agency on behalf of the U.S. government, and by cooperating governments and host institutions abroad.

The deadline for lecturing or research grants is August 1, 1997. Other deadlines are in place for special programs: distinguished Fulbright Chairs in Western Europe and
Canada (May 1) and Fulbright seminars for international education and academic administrators (November 1). For further information and application materials, contact the USIA Fulbright Senior Scholar Program, Council for International Exchange of Scholars, 3007 Tilden Street, NW, Suite 5M, Box GNEWS, Washington, DC 20008-3009, USA; tel: +1-202-686-7877; E-mail (requests for application materials only): CIES1@CIESNET.CIES.ORG; website: HTTP:// WWW.CIES.ORG.

\section{Chautauqua Short Courses}

Several of the 1997 NSF Chautauqua Short Courses for College Teachers may be of interest to members of APLS. "Ethical Implications of the Human Genome Project" will be offered April 17-19 in Austin, Texas by Robert T. Pennock and Alice G. Reinarz of the University of Texas at Austin. "Primate and Human Evolution" will be offered May 19-21 in Stony Brook, New York by John G. Fleagle of the State University of New York at Stony Brook. "Environmentalisms: Rethinking Wilderness and Nature" will be offered May 12-14 in Cambridge, Massachusetts by Everett Mendelsohn of Harvard University. In general, teachers of undergraduate students in degree-granting institutions of higher education in the United States whose teaching responsibilities are in the natural or social sciences, mathematics, or engineering are eligible for participation. Space is restricted. For a brochure that includes an application form, contact Nicholas G. Eror, Chautauqua Program, 323 Benedum Hall, University of Pittsburgh, Pittsburgh, PA 15261. For information about space availability, visit HTTP:/WWW.ENGRNG.PITT.EDU/ CHAUTAUQ/.

\section{Donations for PLS/APLS}

We gratefully acknowledge recent generous gifts from William R. Page (Orleans, Vermont, USA) and a donor who wishes to remain anonymous. Such generosity is important for the journal's and the association's continued growth and development. Subscription and membership fees cover only a small part of the costs of running the association and publishing an international and interdisciplinary journal. If you would like to make a donation to PLS/APLS, please make your check payable to the LSSU Foundation and specify that your gift is for support of the editorial and administrative offices of the Association for Politics and the Life Sciences. Donations should be sent to Association for Politics and the Life Sciences, Lake Superior State University, 650 W. Easterday Ave., Sault Ste. Marie, MI 49783, USA. Unless you indicate a preference for anonymity, we will be pleased to acknowledge your generosity in the newsletter or the journal. 